\title{
Autoimmune thyroiditis presenting as interstitial granulomatous dermatitis
}

\author{
Dermatite intersticial granulomatosa como apresentação de tireoidite \\ autoimune
}

\author{
Joana Antunes ${ }^{1}$ \\ Ana Rita Travassos ${ }^{2}$ \\ Paulo Filipe ${ }^{4}$
}

\author{
David Pacheco ${ }^{2}$ \\ Luís Miguel Soares-Almeida ${ }^{3}$ \\ Manuel Sacramento-Marques ${ }^{5}$
}

\begin{abstract}
A 54-year-old female presented with recurrent, widespread, erythematous, painful plaques, over a 3-month period. Skin biopsy was compatible with interstitial granulomatous dermatitis. Additional investigation revealed hypothyroidism and positive anti-thyroid antibodies. Normalization of thyroid function and high-potency topical corticosteroids provided only transitory improvement of the dermatosis. Interstitial granulomatous dermatitis is a histologic inflammatory reaction, with variable cutaneous expression. It has been reported in association with several drugs, lymphoproliferative diseases and autoimmune disorders, such as rheumatoid arthritis, systemic lupus erythematosus and vasculitis, but association with autoimmune thyroiditis is rare. Optimal therapy for this condition is yet to be established, but topical corticosteroids have been a mainstay of treatment. In most cases, this disease is characterized by flares and remissions.
\end{abstract}

Keywords: Dermatitis; Granulomatous disease, chronic; Thyroiditis; Thyroiditis, autoimmune

Resuimo: Uma doente de 54 anos foi avaliada por placas eritematosas, dolorosas, disseminadas, recorrentes, com 3 meses de evolução. A biopsia cutânea foi compatível com dermatite intersticial granulomatosa. Os restantes exames laboratoriais revelaram hipotiroidismo e anticorpos anti-tiroideus positivos. Apesar da normalização da função tiroideia e de tratamento com corticóide tópico de alta potência, a dermatose melhorou apenas parcialmente. Dermatite intersticial inflamatória é um diagnóstico histopatológico, com expressão clínica variável. Tem sido associada a vários fármacos, doenças linfoproliferativas e autoimunes, nomeadamente artrite reumatóide, lupus eritematoso sistémico e vasculites, mas a associação com tireoidite autoimune é rara. Até ao momento, não foi definido nenhum tratamento específico, mas os corticóides tópicos são dos fármacos mais utilizados. A doença caracteriza-se por períodos de agravamento e remissão.

Palavras-chave: Dermatite; Doença granulomatosa crônica; Tireoidite; Tireoidite auto-imune

Received on 07.09.2011.

Approved by the Advisory Board and accepted for publication on 03.11.2011.

* Study carried out at the Dermatology Service, Santa Maria Hospital, Hospital Center North Lisbon (Hospital de Santa Maria - Centro Hospitalar Lisboa Norte, E.P.E.) - Lisbon, Portugal.

Conflict of interest: None

Financial funding: None

MD - Dermatovenereology hospitalar assistant - Dermatology Service, Santa Maria Hospital, Hospital Center North Lisbon (Hospital de Santa Maria - Centro Hospitalar Lisboa Norte, E.P.E.) - Lisbon, Portugal.

MD - Intern of the Dermatovenereology complementary internship - Dermatology Service, Santa Maria Hospital, Hospital Center North Lisbon (Hospital de Santa Maria - Centro Hospitalar Lisboa Norte, E.P.E.) - Lisbon, Portugal.

MD, PhD - Cutaneous Histopathology Laboratory, Santa Maria Hospital, Hospital Center North Lisbon (Hospital de Santa Maria - Centro Hospitalar Lisboa Norte, E.P.E.) - Lisbon, Portugal.

MD, PhD - Professor of Dermatology - Lisbon School of Medicine (Faculdade de Medicina de Lisboa) - Lisbon, Portugal.

MD - Service Director - Santa Maria Hospital, Hospital Center North Lisbon (Hospital de Santa Maria - Centro Hospitalar Lisboa Norte, E.P.E.) - Lisbon, Portugal 


\section{INTRODUCTION}

Interstitial granulomatous dermatitis (IGD) is an uncommon disease, with characteristic histopathological features but variable clinical expression. When the clinical picture includes arthritis, it takes the name Ackerman's Syndrome, who first described this entity in 1993. ${ }^{1}$ Since then, it has been reported in association with autoimmune diseases, lymphoproliferative disorders and several systemically administered drugs. We report a case of IGD which occurred as the presenting symptom of an underlying autoimmune thyroiditis.

\section{CASE REPORT}

A 54-year-old Caucasian female presented to the emergency room with 2 erythematous, sharply demarcated, painful, indurated plaques, on her left arm and right thigh, which had appeared in the previous $\mathbf{4 8}$ hours. She denied any systemic complaints, emergency laboratory tests revealed only microcytic anemia and slightly elevated C-reactive protein and, therefore, she was discharged and prescribed only conservative measures. When reevaluted, after 1 week, those lesions had resolved, but 2 new similar plaques had appeared over the right arm and left buttock, and linearly arranged erythematous papules had arisen on the right hand (Figure 1).

Skin biopsy showed a diffuse inflammatory infiltrate occupying the whole dermis, with massive subepidermal edema, replete with myeloperoxidase positive $(\mathrm{MPO}+)$ granulocytes, basophilic flame figures and eosinophils, and small incipient granulomas around free-floating collagen bundles, suggestive of IGD (Figure 2 and 3).

The patient had a history of benign breast nodules, iron deficiency anemia and depression, and had been medicated with fluoxetine, lorazepam and acetylsalicylic acid for over 5 years.

Additional laboratory investigation detected subclinical hypothyroidism (free thyroxine $0.72 \mathrm{ng} / \mathrm{dL}$; ref. 0.89-1.80), positive anti-thyroid antibodies (TPO
$1303 \mathrm{U} / \mathrm{mL}$, TG $102 \mathrm{U} / \mathrm{mL}$ ) and thyroid ultrasound revealed a thyroid micronodule. She was medicated with high potency topical corticosteroid and evaluated by an endocrinologist who prescribed levothyroxine. However, despite normalization of thyroid function, there was only transitory improvement of individual lesions, and, after a follow-up of 2 years, new lesions keep on occurring (Figure 4).

\section{DISCUSSION}

IGD is considered to be a histological inflammatory reaction pattern of the granulomatous type, characterized by collagen necrobiosis, in the context of an internal disease with the ability to produce immunocomplexes. Altough the original description reported subcutaneous indurated linear cords ("the rope sign") along the lateral aspect of the trunk, the clinical picture is now known to be quite heterogeneous, as it may also manifest as patches, papules, nodules or plaques, and at different body sites. The dermatosis is traditionally asymptomatic. However, there have also been reports of occasionally pruritic or tender skin lesions, as was the case of our patient. Arthritis is also an inconsistent feature, which may occur prior to, simultaneously with, after the onset of the cutaneous lesions, or not at all. ${ }^{2,3,4}$ It is usually symmetric, nonerosive and non-deforming, affecting mainly the joints of the upper limbs. ${ }^{4}$ This variety of clinical presentations makes diagnosis difficult, and histological characteristics are usually essential for an accurate interpretation of the disease.

The typical microscopic presentation should be that of a granulomatous dermatitis, with palisading or interstitial histiocytes, variable numbers of neutrophils and eosinophils, and scattered areas of degenerating collagen bundles. Accentuation of the process in the reticular dermis is a characteristic feature, although abnormalities can involve the full thickness of the dermis or the superficial hypodermis. ${ }^{5}$
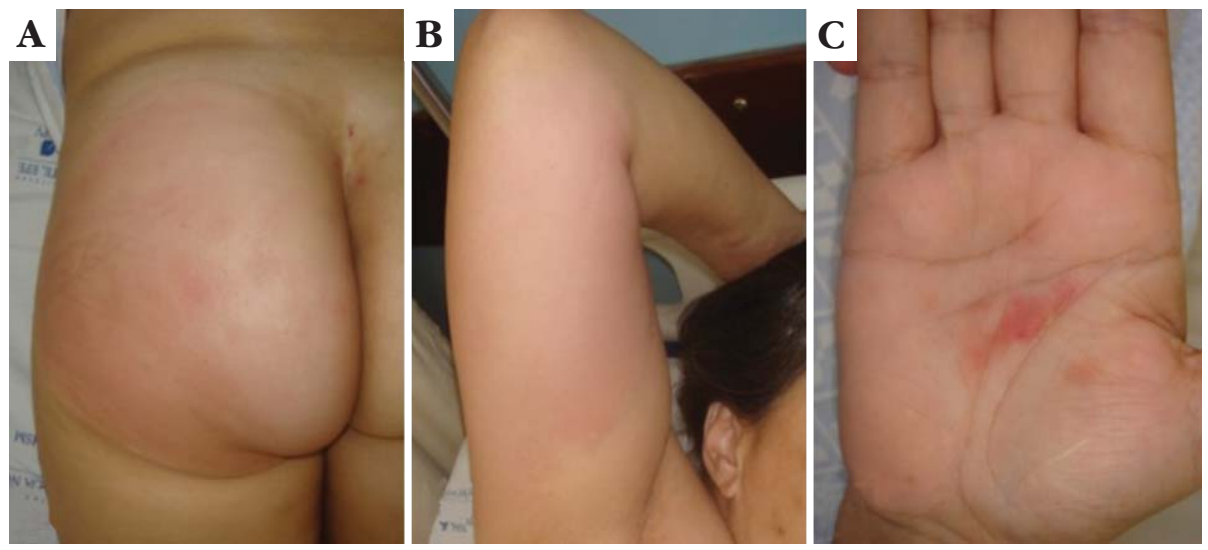

FIGURE 1: Erythematous, tender, sharply demarcated plaques over left buttock (a) and right arm (b); linearly arranged, bright, erythematous papules on right palm (c) 


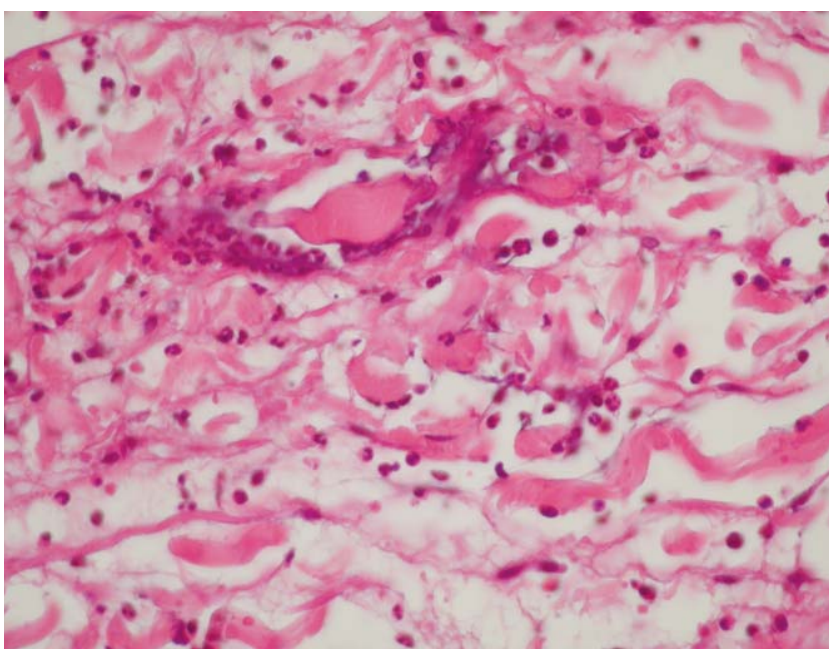

Figure 2: H\&E, x400, Photomicrograph showing dermal edema, basophilic flame figures and small incipient granulomas around free-floating collagen bundles

Different patterns that have also been described may represent different stages or a variable expression of the disease.

For the time being, IGD is considered to be an idiopathic condition. However, the growing number of reports linking it to a variety of autoimmune disorders, namely rheumatoid arthritis, systemic lupus erythematosus and Churg-Strauss syndrome, strongly support the hypothesis of an underlying autoimmune process. IGD may also be the heralding symptom for lymphoproliferative diseases, solid organ cancer, or represent an adverse drug reaction, including to the

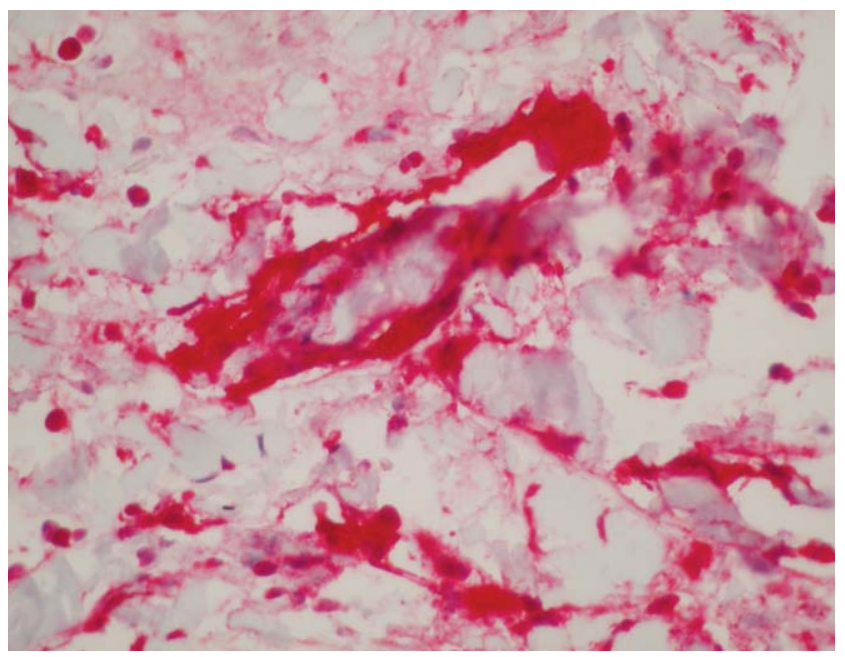

FIGURE 3: Myeloperoxidase (MPO), x400, Photomicrograh showing MPO positive granulocytes
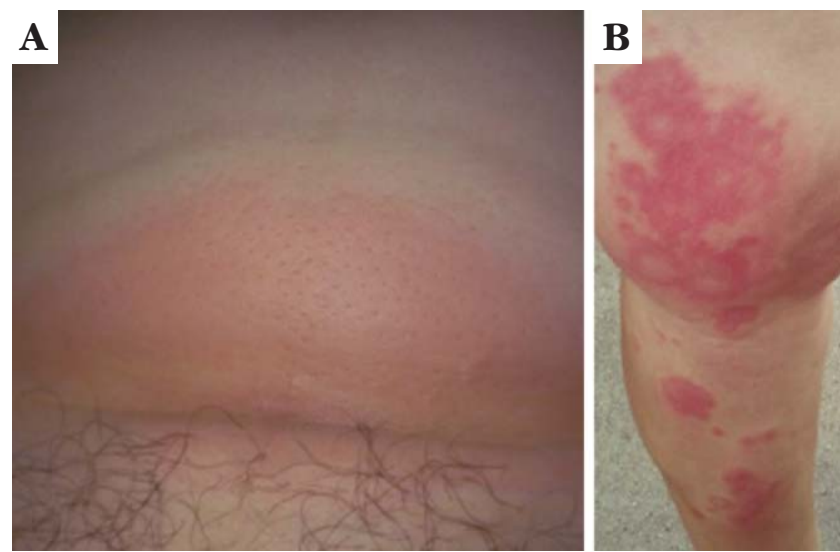

FigurE 4: New erythematous sharply demarcated plaques on abdomen (a) and left leg (b), despite treatment and normal thyroid function

newer biologic agents. ${ }^{2,3,6,7}$ Therefore, once a diagnosis of IGC is made, it is mandatory to thoroughly screen the patient to exclude an associated condition or a causative drug. Our patient showed decreased levels of free thyroxine and high titers of anti-thyroid antibodies, disclosing a previously unrecognized autoimmune thyroiditis. Autoimmune thyroiditis has already been mentioned once in association with IGD. ${ }^{8}$ In that report, the dermatosis spontaneously remitted after 1 year.

The lack of randomized clinical studies has prevented an optimal treatment for IGD to be determined. Topical corticosteroids appear to be only moderately effective, but are still a first line treatment, especially in patients with localized disease. In the case of our patient, topical clobetasol cleared a few established plaques, but did not prevent other lesions from appearing, nor did the normalization of thyroid function. Anectodal reports account for the effectiveness of systemic corticosteroids, antimalarials, cyclosporine, methotrexate, dapsone, cyclophosphamide, anti-tumor necrosis factor $\alpha$ agents or withdrawal of the offending drug. ${ }^{4,9,10}$ Spontaneous resolution and alternating periods of flares and remission, have also been reported for IGD, making its outcome unpredictable. Thus far, no other treatment has been tried on this patient, due to her poor compliance with treatment and difficult follow-up.

In conclusion, IGD is an uncommon skin disease that may be secondary to an underlying systemic condition. Therefore, dermatologists should be aware of this possibility, since they are in a privileged position to diagnose potentially life-threatening diseases, at an early stage. 


\section{REFERENCES}

1. Ackerman AB, Guo Y, Vitale P, Vossaert K. Clues to diagnosis in dermatopathology. 3v. Chicago: ASCP Press; 1993. p.309-12.

2. Deng A, Harvey V, Sina B, Strobel D, Badros A, Junkins-Hopkins JM, et al. Interstitial granulomatous dermatitis associated with the use of tumor necrosis factor $\alpha$ inhibitors. Arch Dermatol. 2006;142:198-202.

3. Swing DC Jr, Sheehan DJ, Sangüeza OP, Woodruff RW. Interstitial granulomatous dermatitis secondary to acute promyelocytic leukemia. Am J Dermatopathol. 2008;30:197-9.

4. Busquets-Pérez N, Narvaez J, Valverde-García J. Interstitial granulomatous dermatitis with arthritis (Ackerman syndrome). J Rheumatol. 2006;33:1207-9.

5. Weedon D. The granulomatous reaction pattern. In: Houston M, Davie B, editors. Weedon's skin pathology. 3rd ed. London: Churchill Livingstone; 2010. p.191-3.

6. Balin SJ, Wetter DA, Kurtin PJ, Letendre L, Pittelkow MR. Myelodysplastic syndrome presenting as generalized granulomatous dermatitis. Arch Dermatol. 2011;147:331-5.

7. Schreckenberg C, Asch PH, Sibilia J, Walter S, Lipsker D, Heid E, et al. Interstitial granulomatous dermatitis and paraneoplastic rheumatoid polyarthritis disclosing cancer of the lung. Ann Dermatol Venereol. 1998;125:585-8.

8. Aloi F, Tomasini C, Pippione M. Interstitial granulomatous dermatitis with plaques. Am J Dermatopathol. 1999;21:320-3.

9. Felcht M, Faulhaber J, Göttmann U, Koenen W, Goerdt S, Goebeler M. Interstital granulomatous dermatitis (Ackerman's syndrome). Eur J Dermatol. 2010;20:661-2.

10. Dubey S, Merry P. Instertitial granulomatous dermatitis (Ackerman's syndrome) in SLE presenting with the 'rope sign'. Rheumatology (Oxford). 2007;46:80.

\author{
MAILING ADDRESS: \\ Joana Antunes \\ Serviço de Dermatologia - Hospital de Santa Maria \\ Av. Prof. Egas Moniz \\ 1649-035 Lisboa, Portugal \\ E-mail: joanaferroantunes@gmail.com
}

How to cite this article: Antunes J, Pacheco D, Travassos AR, Soares-Almeida LM, Filipe P, Sacramento-Marques M. Autoimmune thyroiditis presenting as interstitial granulomatous dermatitis. An Bras Dermatol. 2012;87(5):748-51. 